\title{
Assessment of chemistry of soil irrigated on Phuleli canal
}

\author{
Ghulam Murtaza Mastoi ${ }^{1}$, Baradi Waryani ${ }^{2}$, Zulfiqar Ali Laghari ${ }^{3}$, Zameer Ali Palh ${ }^{2, *}$, \\ Khalid Hussain Lashari ${ }^{2}$, Khalida Faryal Almani ${ }^{1}$, Gul- e-Rana ${ }^{4}$, Abdul Waheed Mastoi ${ }^{1}$ \\ ${ }^{1}$ Centre for Environmental Sciences, University of Sindh, Jamshoro, Sindh, Pakistan \\ ${ }^{2}$ Department of Fresh Water Biology and fisheries, University of Sindh, Jamshoro, Sindh, Pakistan \\ ${ }^{3}$ Department of Physiology, University of Sindh, Jamshoro, Sindh, Pakistan \\ ${ }^{4}$ Department of P.C.S.I.R Karachi, Sindh, Pakistan
}

Email address:

zameer_ali110@hotmail.com (Z.A.Palh)

\section{To cite this article:}

Ghulam Murtaza Mastoi, Baradi Waryani, Zulfiqar Ali Laghari, Zameer Ali Palh, Khalid Hussain Lashari, Khalida Faryal Almani, Gul- eRana, Abdul Waheed Mastoi. Assessment of Chemistry of Soil Irrigated on Phuleli Canal. Science Journal of Chemistry.

Vol. 2, No. 4, 2014, pp. 33-37. doi: 10.11648/j.sjc.20140204.12

\begin{abstract}
Phuleli canal in Hyderabad is main water supply source for both irrigation as well as human drinking purpose. Quality of the canal deteriorates while passing through Hyderabad city,2nd largest city of Sindh ,Pakistan because highly toxic effluent from plastic factories, illigale cattle pens, slaughterhouses and munciple sewage water are directly discharge into the phuleli canal without any treatment. Soil is a basic requirement for supporting the life on earth, but all over the world soil fertility decreasing by different ways including waste water and solid waste. In Pakistan soil is polluted by different ways out of which untreated liquid waste is main cause of soil pollution. The sewage and industrial liquid waste released in canals and streams without any treatment, which used for irrigation by which soil get polluted. This study was carried out to find out the facts about soil pollution by sewage, in this purpose Phuleli canal was selected, this canal carry the liquid waste of Hyderabad and for the desired study different parameters were investigated.
\end{abstract}

Keywords: Sewage, Liquid Waste, Irrigation, Soil Pollution

\section{Introduction}

Sewage contains organic matter, heavy metals, organic compounds, and human pathogens which are extremely harmful when sewage utilized in agricultural for irrigation (A.Khan, et al., 1994;Wagner Bettiol and Raquel Ghini, 2011). Contamination by heavy metals in soils also strongly affects the environmental quality (Mohammad Wahsha et al., 2012).

Phuleli is an irrigation canal and is located in Sindh at Latitude: 25'10'11.92" and Longitude: 68 $28^{\prime} 23.26^{\prime \prime}$, Pakistan. The elevation of canal is 21 meters. Phuleli canal takes off from left bank of Indus River at kotri barrage to transfer river water for agriculture purpose in Hyderabad and sujawal sub-division. Hyderabad city with a population of about 1.5 million is throwing its untreated sewage, mostly from northern part into Phuleli canal while passing through the city, sewage is added from different locations i.e from cantonment area where water is pumped into the Phuleli canal, sewage from Hirabad, Khuwaja colony, Silawat para and Northern part of Liaqat colony is collected in a main drain (nallah) which flows by gravity into the Phuleli canal near Kali Mori, sewage pumped into canal near village Darya Khan Panhwar and from an old Power House situated near Phuleli canal.

Phuleli also accepts all of sewerage of Hyderabad city, toxic substance of vehicles and bangle industries, liquid waste of slaughter houses and poultries and also heavily contaminated affluent of industries from Hala Naka to Husri and the affluent also includes Asia's biggest cement factory the Zeal Pak. There are numbers of Villages surrounding near to phuleli canal, Therefore population of living near to phuleli canal at risk of human health problem.

Untreated Sewage contain lot of Heavy metals (N. Sridhara Chary et al., 2008) which affect on soil microbial activity (P. C. Brookes and S. P. Mc Grath, 2006), Sewage affects aquatic bodies (K.-J. winter and D. Goetz, 2003), different types of crops and soil (Steve et al., 1995;Raül S. 
Lavado, 2006;) and underground water quality (S.C. Wilson et al., 1996). Sludge in sewage also unease for organisms and the environment (M. Ghaedi et al., 2008; Ulrika Olofsson et al., 2012). Soil pollution decrease crop yields (Munir J. et al., 2007).

Prosperity of Pakistan is depending on Agriculture, but agriculture of Pakistan decreasing dramatically due to damaging of soil fertility. Untreated sewage is the largest cause of soil pollution in Pakistan (Muhammad K. Jamali et al.,2009) this sewage contains large number of contaminates, which rests on soil, when soil irrigated by water containing untreated sewage (K.P. Singh et al., 2004).

\section{Material and Method}

Five stations were selected for the soil sampling beside the Phuleli canal. Sample No.1 from C.I.A center, Sample No.2 from Bhatti Village, Sample No.3 from Darya Khan Panhwar Village, Sample No.4 from Nara Jail and sample No.5 from Pono Koli Village near Zeal Pak (Lorlyn Reidy et al., 2013).

The samples were analyzed for loss in weight on air drying at $400 \mathrm{C}$, loss of weight at $1050 \mathrm{C}$ and $5500 \mathrm{C}$ (Margarita Miranda et al., 2010), pH, Conductivity, chlorides, Phosphate nitrate, iron, manganese, zinc, copper, nickel, cobalt, lead, chromium and cadmium (Liu et al., 2006; Liu et al., 2007; Li et al., 2010; Zhao et al., 2012;Zhiyuan Li et al., 2014).

The sampling stations were based in agricultural fields. Samples were brought in laboratory, after drying and gridding; solution was prepared and filtered with Whitman 42 filter paper in $100 \mathrm{ml}$ flask, marked to $100 \mathrm{ml}$ with deionized water (Liu et al., 2006; Liu et al., 2007; Li et al., 2010).

$\mathrm{pH}$ was noted with $\mathrm{pH}$ meter and conductivity was measured by pre calibrated Orion 115 conductivity meter with pre cleaned electrode by inserting it in the water body of samples.

For determination of Chloride samples were noted by dissolved $(25 \mathrm{~g})$ in $10 . \mathrm{ml}$ quantity of distilled water (few drops) silver nitrate solution was added in order to produced slight red precipitated, allowed to stand overnight and filtered. The volume was made up to 1 liter with deionized water. Silver nitrate by dissolved $(2.48 \mathrm{~g})$ silver nitrate in 1 liter deionized water. Sodium chloride by dissolved (16.28g) sodium chloride in 1 liter deionized water. Silver nitrate solution was standardized with sodium chloride solution using potassium chromate solution as indicator.

Two dishes were taken, one dish $25 \mathrm{ml}$ water sample in other dish $50 \mathrm{ml}$ distilled water were added.1.0 $\mathrm{ml}$ of potassium chromate solution was also added in each dish. Standardized silver nitrate was filled in the burette and added drop in the sample dish until first reddish color appeared, compared this with the original color of the distilled water and chromate mixture in the second dish, the consumed volume of silver nitrate was measured.

The soil samples were also analyzed for metal content of iron, manganese, copper, nickel. Cobalt, lead, chromium and cadmium (Raül S. Lavado, 2006). After acid digestion and
Atomic-absorption (AA) spectrophotometer was used.

\section{Result and Discussion}

Heavy metals contaminations threatening human health by their impact on ecosystems, water and food quality (Bini et al., 2010 and Lim et al., 2008). In Pakistan various kind of researches has been carried out on soil pollution by contaminated water (S.T. Abbas et al., 2007) studied contaminated water of Nullah Dek on fine rice paddy and straw yields and trace elements accumulation in different parts of rice plants and soil, near the bank of Nullah Dek at Kot Pindi Das in the District of Sheikhupura, Pakistan. (A. Ghafooret et al., 1994) worked on chemical composion of effluentsfrom different industries of Faisalabad city. (M Qadir et al., 1997) investigate metal ion contamination in vegetables and soils irrigated with city effluents. (S.Khan et al., 2002) worked on investigation of pollutant load in waste water of hayatabad, Peshawar.

Loss on ignition corresponded to the organic portion and fluctuated between 0.786 to $5.22 \%$. $\mathrm{pH}$ of soil was observed with acceptable limits of 7.18 to 8.32 for irrigation purpose, it is may be due to heavy organic and inorganic load in soil . The soil extract (1:2) analyzed for conductivity and nitrate indicated the parallel results with over all ranges observed during the study were 260 to $1560 \mu \mathrm{S} / \mathrm{Cm}$, (Table.1.) and 0.285 to $8.815 \mathrm{mg} / 100 \mathrm{~g}$ (Table.1.) respectively.

(B.J. Radford et al., 2009) studied on soil chloride and deep drainage response to lend clearing for cropping at seven sites in central Queensland, northern Australia. (Sheldon et al., 2004).worked on effect of salinity on plant available water. (Changrong $\mathrm{Ke}$ et al.,2013).studied on impacts of chlorides de-icing salts on bluck soils fungi and bacterial pollutions surrounding the plants rhizosphere. (Sheldon et al., 2004). Worked on effect of salinity on plant available water (Changrong Ke et al., 2013).Studied on impacts of chlorides de-icing salt bulk soils,fungi, and bacterial population surrounding the plant rhizosphere.

The result of soil analysis indicated acceptable values of $\mathrm{pH}$, nitrogen and phosphorus contents for the irrigation purpose. The concentration of the toxic metal ions lead, chromium and were present up to $37.291 \mu \mathrm{g} / \mathrm{g}$ and $34.78 \mu \mathrm{g} / \mathrm{g}$ respectively. It was found that samples from upward were less contaminated than down ward and it may be due to excessive disposal of untreated sewage. Untreated Sewage impacts aquatic bodies, soil and food. It is harmful to al organisms. Metal ions are non degradable they magnify in organism. They may cause damage nervous system (lead). High concentration of these metallic ions may also cause alteration of metabolism and genetic mutation.

The metal ions in soil were present at largest concentration; Metals are bound to soil materials by different chemical bonds (G.Q.Liu et al., 2006). Zinc was within the range of 2.158 to $77.69 \mu \mathrm{g} / \mathrm{g}$ (Zinc), other hand (EPA. S.R.O. 549 (I)/2000) limit for zinc is $5 \mathrm{mg} / \mathrm{l}$, highest concentration of zinc was found in sample No.4, which was collected from near Nara Jail. 
Iron is not considered toxic unless its highest concentration above than $1000 \mathrm{mg} / \mathrm{g}$ (A.Kabata-Pendias, 2007). In study area concentration of iron was up to 17 microgram per gram and this was in sample 3, collected from Darya Khan Panhwar Village. According (EPA. S.R.O. 549 (I)/2000) limit of iron is $8 \mathrm{mg} / \mathrm{l}$.

Halim Avci and Tugrul Deveci, 2013 investigate contamination of field soil and crops results from irrigation using municipal and industrial wastewater. According to their study Cadmium is not an essential plant nutrient and can have toxic effects at relatively low concentrations. In study area high concentration of cadmium was found in sample 4, Up to $10 \mathrm{ug} / \mathrm{g}$ (Fig.13), so it may accumulate in tissues of plants and easily transferred to consumers.

Cobalt is micronutrient for soil but other concentration of metls may inhibit its required amount in soil. According to (A.Kabata-Pendias and Mukherjee, 2007;S.T.Abbas, et al.,2007and R.X.Zhao, et al.,2012) the concentrations of Coin plant foodstuffs vary from 8 to $170 \mu \mathrm{g} \mathrm{kg}-1$; tomato fruit concentrations were $20-62 \mu \mathrm{g} \mathrm{kg}-1$. Leafy plants, such as lettuce, cabbage and spinach have a relatively high Co content, whereas Co is lower in grasses and cereals, this study was carried out in Turkey. In current study Co was found up to16.5 ug/g (Table.1).

Copper concentration was found up to $24.94 \mathrm{ug} / \mathrm{g}$ (Table.1), (EPA. S.R.O. $549(\mathrm{I}) / 2000)$ its limit is $1 \mathrm{mg} / \mathrm{l}$. copper is essential element but its excess may result in membrane damage and suppression of enzyme activities (B.AlaouiSosse et al., 2004).. Other hand (Halim Avci and Tugrul Deveci, 2013) reported that when $\mathrm{pH}$ accedes than 7 availability of copper reduced drastically. Interactions between $\mathrm{Ca}$ and $\mathrm{Cu}$ may also affect the bioavailability of $\mathrm{Cu}$ (A.Kabata-Pendias and Mukherjee, 2007 S.T.Abbas, et al.,2007; R.Zahao et al.,2012).

Nickel is study area was found up to $32 \mathrm{ug} / \mathrm{g}$ (Table.1). (Adriano, 2001 S.T.Abbas, et al.,2007) reported that nickel concentrations in field-grown crops and natural vegetation range from 0.05 to $5.0 \mathrm{mg} \mathrm{kg}$. According (EPA. S.R.O. 549 (I)/2000) standard limit of nickel in waste water is $1 \mathrm{mg} / \mathrm{l}$.

Lead is another non essential element in soil. In current study ead concentration was found up to $35 \mathrm{ug} / \mathrm{g}$ (Table.1). This is highest concentration can be understated from (EPA. S.R.O. 549 (I)/2000) according which standard limit of lead is $0.5 \mathrm{mg} / \mathrm{l}$. Mean $\mathrm{Pb}$ concentrations in food plants grown in several countries range from 0.2 to $2.4 \mathrm{mg} \mathrm{kg}$ (Halim.Avci and Tugrul Deveci, 2013).

Table 1. Quantitative analysis of soil irrigated on Phuleli canal water, average value $(n=8)$ with \pm confidence interval at $95 \%$. The values in percentage are minimum maximum

\begin{tabular}{|c|c|c|c|c|c|}
\hline Parameters & Near C.I.A Centre & Bhatti Village & $\begin{array}{l}\text { Darya Khan Panhwar } \\
\text { Village }\end{array}$ & Nara Jail & $\begin{array}{l}\text { Pono Koli Village } \\
\text { near Zeal Pak }\end{array}$ \\
\hline $\mathrm{pH}$ values & $\begin{array}{l}7.87 \pm 0.54 \\
(7.18-8.22)\end{array}$ & $\begin{array}{l}7.72 \pm 0.28 \\
(7.40-8.30)\end{array}$ & $\begin{array}{l}7.83 \pm 24 \\
(7.54-8.24)\end{array}$ & $\begin{array}{l}7.93 \pm 0.22 \\
(7.66-8.32)\end{array}$ & $\begin{array}{l}7.97 \pm 0.311 \\
(7.53-8.33)\end{array}$ \\
\hline Conductivity $\mu \mathrm{S} / \mathrm{Cm}$ & $\begin{array}{l}654.57 \pm 239 \\
(423-1180)\end{array}$ & $\begin{array}{l}583 \pm 171 \\
(420-869)\end{array}$ & $\begin{array}{l}787.5 \pm 410.3 \\
(260-1560)\end{array}$ & $\begin{array}{l}622.2 \pm 287.2 \\
(1360-1200)\end{array}$ & $\begin{array}{l}698.6 \pm 235.4 \\
(603-1060)\end{array}$ \\
\hline Loss of Air drying at $40 \mathrm{oC}(\%)$ & $\begin{array}{l}2.98 \pm 2.57 \\
(0.294-7.27)\end{array}$ & $\begin{array}{l}3.345 \pm 2.632 \\
(0.140-8.80)\end{array}$ & $\begin{array}{l}787.5 \pm 3.282 \\
(0.242-9.380)\end{array}$ & $\begin{array}{l}3.613 \pm 4.684 \\
(0.288-13.34)\end{array}$ & $\begin{array}{l}2.583 \pm 1.3 \\
(0.237-9.594)\end{array}$ \\
\hline Loss of $\mathrm{H} 2 \mathrm{O}$ at $105 \mathrm{oC}(\%)$ & $\begin{array}{l}3.0561 \pm 2.9 \\
(0.287-9.38)\end{array}$ & $\begin{array}{l}3.948 \pm 2.2189 \\
(0.89-8.80)\end{array}$ & $\begin{array}{l}3.255 \pm 3.040 \\
(0.505-9.747)\end{array}$ & $\begin{array}{l}3.436 \pm 0.986 \\
(0.34-8.076)\end{array}$ & $\begin{array}{l}1.035 \pm 0.863 \\
(0.75-5.00)\end{array}$ \\
\hline Loss on ignition at $550 \mathrm{oC}(\%)$ & $\begin{array}{l}2.593 \pm 0.99 \\
(0.786-3.8)\end{array}$ & $\begin{array}{l}3.1310 \pm 1.227 \\
(1.285-5.22)\end{array}$ & $\begin{array}{l}0.853 \pm 0.458 \\
(1.95-3.517)\end{array}$ & $\begin{array}{l}3.052 \pm 1182 \\
(1.517-3.965)\end{array}$ & $\begin{array}{l}2.69 \pm 1.0281 \\
(1.148-3.94)\end{array}$ \\
\hline Chloride $\mu \mathrm{g} / \mathrm{g}$ & $\begin{array}{l}1.112 \pm 1.02 \\
(0.489-380)\end{array}$ & $\begin{array}{l}1.507 \pm 1.505 \\
(0.498-4.328)\end{array}$ & $\begin{array}{l}0.759 \pm 0.1775 \\
(0.803-2.203)\end{array}$ & $\begin{array}{l}0.650 \pm 0.162 \\
(0.498-0.708)\end{array}$ & $\begin{array}{l}0.877 \pm 0.191 \\
(0.492-0.708)\end{array}$ \\
\hline Phosphate $\mu \mathrm{g} / 100 \mathrm{~g} \mathrm{n}=5$ & $\begin{array}{l}1.30 \pm 1.367 \\
(0.30-3.02)\end{array}$ & $\begin{array}{l}1.363 \pm 1.084 \\
(0.137-2.62)\end{array}$ & $\begin{array}{l}1.425 \pm 0.719 \\
(0.803-2.348)\end{array}$ & $\begin{array}{l}1.246 \pm 1.234 \\
(0.241-3.5)\end{array}$ & $\begin{array}{l}2.346 \pm 2.521 \\
(0.241=252)\end{array}$ \\
\hline Nitrate $\mu \mathrm{g} / 100 \mathrm{~g}$ & $\begin{array}{l}3.326 \pm 2.40 \\
(0.65-8.815)\end{array}$ & $\begin{array}{l}2.266 \pm 0.853 \\
(1.04-3.8)\end{array}$ & $\begin{array}{l}2.879 \pm 1.403 \\
(1.881-5.93)\end{array}$ & $\begin{array}{l}1.746 \pm 1.218 \\
(0.285-3.757)\end{array}$ & $\begin{array}{l}2.557 \pm 1.268 \\
(0.516-4.285)\end{array}$ \\
\hline $\mathrm{Fe} \mu \mathrm{g} / \mathrm{g}$ & $\begin{array}{l}14.99 \pm 7.80 \\
(2.622-27.4)\end{array}$ & $\begin{array}{l}16.136 \pm 7.438 \\
(2.55-26.967)\end{array}$ & $\begin{array}{l}17.021 \pm 5.895 \\
(7.97-27.23)\end{array}$ & $\begin{array}{l}12.693 \pm 7.89 \\
(2.158-24.8)\end{array}$ & $\begin{array}{l}9.885 \pm 5.495 \\
(5.82-13.117)\end{array}$ \\
\hline $\mathrm{Mn} \mu \mathrm{g} / \mathrm{g}$ & $\begin{array}{l}0.415 \pm 0.06 \\
(10.295-0.5)\end{array}$ & $\begin{array}{l}0.414 \pm 0.0705 \\
(0.28-0.539)\end{array}$ & $\begin{array}{l}0.379 \pm 0.073 \\
(0.281-0.49)\end{array}$ & $\begin{array}{l}0.414 \pm 0.053 \\
(0.38-0.484)\end{array}$ & $\begin{array}{l}0.5706 \pm 0.388 \\
(0.372-0.415)\end{array}$ \\
\hline $\mathrm{Zn} \mu \mathrm{g} / \mathrm{g}$ & $\begin{array}{l}61.70 \pm 27.8 \\
(8.75-3445)\end{array}$ & $\begin{array}{l}76.714 \pm 44.416 \\
(8.0-108)\end{array}$ & $\begin{array}{l}58.7555 \pm 367.73 \\
(9.0-163.2)\end{array}$ & $\begin{array}{l}77.69 \pm 42.366 \\
(62.5-129.7)\end{array}$ & $\begin{array}{l}63.149 \pm 38.02 \\
(46.1-73.75)\end{array}$ \\
\hline $\mathrm{Cu} \mu \mathrm{g} / \mathrm{g}$ & $\begin{array}{l}22.5 \pm 11.49 \\
(23.8-34.5)\end{array}$ & $\begin{array}{l}16.836 \pm 10.025 \\
(17.0-43.5)\end{array}$ & $\begin{array}{l}24.94 \pm 9.238 \\
(18.8-32.5)\end{array}$ & $\begin{array}{l}22.48 \pm 19.82 \\
(17.5-57.5)\end{array}$ & $\begin{array}{l}19.482 \pm 11.33 \\
(17.5-35.28)\end{array}$ \\
\hline Ni $\mu \mathrm{g} / \mathrm{g}$ & $\begin{array}{l}32.05 \pm 21.6 \\
(29-77.7)\end{array}$ & $\begin{array}{l}26.838 \pm 10.25 \\
(27-42.5)\end{array}$ & $\begin{array}{l}24.942 \pm 9.238 \\
(28.8-50.5)\end{array}$ & $\begin{array}{l}22.489 \pm 16.827 \\
(38.5-83)\end{array}$ & $\begin{array}{l}19.482 \pm 11.339 \\
(30.75-45.25)\end{array}$ \\
\hline Co $\mu \mathrm{g} / \mathrm{g}$ & $\begin{array}{l}11.629 \pm 8.501 \\
(8.7-24)\end{array}$ & $\begin{array}{l}9.052 \pm 4.439 \\
(9.0-13.5)\end{array}$ & $\begin{array}{l}13.9 \pm 3.025 \\
(11.0-15.0)\end{array}$ & $\begin{array}{l}15.916 \pm 3.938 \\
(10.75-80.0)\end{array}$ & $\begin{array}{l}16.583 \pm 3.855 \\
(9.0-26.75)\end{array}$ \\
\hline $\mathrm{Pb} \mu \mathrm{g} / \mathrm{g}$ & $\begin{array}{l}25.87 \pm 17.5 \\
(24.62 .25)\end{array}$ & $\begin{array}{l}20.835 \pm 12.275 \\
(18.0-38.5)\end{array}$ & $\begin{array}{l}37.291 \pm 10.95 \\
(20.5-58.0)\end{array}$ & $\begin{array}{l}35.82 \pm 19.143 \\
(21.5-57.0)\end{array}$ & $\begin{array}{l}21.89 \pm 16.856 \\
(13.2-39.5)\end{array}$ \\
\hline $\mathrm{Cr} \mu \mathrm{g} / \mathrm{g}$ & $\begin{array}{l}32.2 \pm 10.11 \\
(17.8-51.2)\end{array}$ & $\begin{array}{l}17.93 \pm 10.49 \\
(13.5-37.0)\end{array}$ & $\begin{array}{l}25.73 \pm 15.29 \\
(13.0-0.60)\end{array}$ & $\begin{array}{l}34.78 \pm 20.378 \\
(33.5-63.61)\end{array}$ & $\begin{array}{l}25.856 \pm 15.93 \\
(20-48)\end{array}$ \\
\hline $\mathrm{Cd} \mu \mathrm{g} / \mathrm{g}$ & $\begin{array}{l}5.85 \pm 1.601 \\
(10.3-4.0)\end{array}$ & $\begin{array}{l}2.295 \pm 1.503 \\
(0.325-4.0)\end{array}$ & $\begin{array}{l}3.66 \pm 0.5387 \\
(3.0-4.75)\end{array}$ & $\begin{array}{l}10.2 \pm 11.587 \\
(3.25-5.0)\end{array}$ & $\begin{array}{l}9.916 \pm 3.096 \\
(3.0-7.5)\end{array}$ \\
\hline
\end{tabular}


$\mathrm{Cd} / \mathrm{Zn}$ ratio in plant tissues is usually 0.01 or less (Kelling et al., 1977) Same kind of results were also got from these studies (Khan et al., 1994; Younas et al., 1999; Ibrahim et al., 1998; Ghafoor et al., 1995; Ghafoor et al., 1996; Ghafoor et al., 1999).

\section{Acknowledgement}

Authors gratefully acknowledge the financial support by University of Sindh.

\section{References}

[1] A. Frostick, A. Bollhöfer, D. Parry, N. Munksgaard, K. Evans. Radioactive and radiogenic isotopes in sediments from Cooper Creek, Western Arnhem Land. Journal of Environmental Radioactivity. Volume 99, Issue 3, March 2008, Pages 468482

[2] A. Kabata-Pendias .Trace Elements in Soils and Plants (4th ed.), CRC Press, Boca Raton (2011), p. 548

[3] A. Ghafoor , A. Rauf, M. Arif, W. Muzaffar. Chemical composition of effluents from different industries of the Faisalabad city. Pak. J. Agric. Sci., 31 (1994), pp. 367-369

[4] A. Ghafoor, A. Rauf, W. Muzaffar. Irrigation with Madhuana drains water: Impact on soils and vegetables (spinach and cauliflower) at Faisalabad. J. Drain. Recl., 7 (1995), pp. 7-12

[5] A. Ghafoor, A. Rauf, M. Arif. Soil and plant health irrigated with Paharang drain sewage effluents at Faisalabad. Pak. J. Agric. Sci., 33 (1996), pp. 73-76

[6] A. Kabata-Pendias, A.B. Mukherjee. Trace Elements from Soil to Human. Springer, New York (2007)

[7] A. Ghafoor, S. Ahmad, M. Qadir, S.I. Hussain, G. Murtaza. Formation and leaching of lead species from a sandy loam alluvial soil as related to $\mathrm{pH}$ and $\mathrm{Cl}: \mathrm{SO} 4$ ratio of leachates. J. Int. Agric. Biol., 3 (1999), pp. 82-84

[8] A. Khan, M. Ibrahim, N. Ahmad, S. Ahmad. Studies on accumulation and distribution of heavy metals in agricultural soils receiving sewage effluents irrigation. Soil Science of Pakistan Proceedings of the 4th Annual Conference, Islamabad (1994)

[9] Anneli Joutti, Marja-Liisa Räisänen, Petri Lintinen, Esko Martikainen, Olli Lehto. Extractability of metals and ecotoxicity of soils from two old wood impregnation sites in Finland. Science of The Total Environment. Volume 326, Issues 1-3, 29 June 2004, Pages 71-84

[10] B. Alaoui-Sossé, P. Genet, F. Vinit-Dunand, M-L. Toussaint, D Epron, P-M. Badot. Effect of copper on growth in cucumber plants (Cucumis sativus) and its relationships with carbohydrate accumulation and changes in ion contents. Plant Sci., 166 (2004), pp. 1213-1218

[11] B.J. Radford, D.M. Silburn, B.A. Forster. Soil chloride and deep drainage responses to land clearing for cropping at seven sites in central Queensland, northern Australia. Journal of Hydrology. Volume 379, Issues 1-2, 15 December 2009, Pages 20-29
[12] C. Bini, S. Fontana, M. Wahsha. Soil contamination by mine dumps, plant toxicity and restoration perspectives by phytoremediation. Air, water, and soil pollution, Environmental Quality, vol. 4 (2010), pp. 173-180

[13] Changrong Ke, Zhouyuan Li, Yingmei Liang, Wanqiang Tao, Mengchan Du. Impacts of chloride de-icing salt on bulk soils, fungi, and bacterial populations surrounding the plant rhizosphere. Applied Soil Ecology. Volume 72, October 2013, Pages 69-78

[14] D.C. Adriano. Trace Elements in Terrestrial Environments. (second ed.)Springer-Verlag, New York (2001)

[15] G.Q. Liu, C.H. Liang, L.Y. Du, X.Z. Chen, F. Wang. Primary study of heavy metal contamination of soil in the area of Hongtou Mountains. Chin Agric Sci Bull, 22 (2006), pp. 364 367.

[16] Halim Avci and Tuğrul Deveci. Assessment of trace element concentrations in soil and plants from cropland irrigated with wastewater.Ecotoxicology and Environmental Safety. Volume 98, 1 December 2013, Pages 283-29

[17] H.S. Lim, J.S. Lee, H.T. Chon, M. Sager. Heavy metal contamination and health risk assessment in the vicinity of the abandoned Songcheon Au-Ag mine in Korea. Journal of Geochemical Exploration, 96 (2008), pp. 223-230

[18] J.C. Li, R.Z. Yin, Y.P. Luo, Y.L. Lu, L.D. Zhang. Assessment of heavy metal contamination of soils in Daxin manganese mine, Guangxi. Environ Sci Technol, 33 (2010), pp. 183-186.

[19] K.J. Winter and D. Goetz, The impact of sewage composition on the soil clogging phenomena of vertical flow constructed wetlands. Water science technology volume 49 no 5 page 9-14 (2003)

[20] K.P. Singh, D. Mohan, S. Sinha, R. Dalwani. Impact assessment of treated/untreated waste water toxicants, discharge by sewage treatment plants, on health, agricultural, and environmental quality in wastewater disposal area. Chemosphere, 55 (2004), pp. 227-255

[21] Lorlyn Reidy, Kaixuan Bu, Murrell Godfrey, James V. Cizdziel. Elemental fingerprinting of soils using ICP-MS and multivariate statistics: A study for and by forensic chemistry majors. Forensic Science International. Volume 233, Issues 13, 10 December 2013, Pages 37-44

[22] Margarita Miranda, Antonio Vega-Gálvez, Jéssica López, Gloria Parada, Mariela Sanders, Mario Aranda, Elsa Uribe, Karina Di Scala. Impact of air-drying temperature on nutritional properties, total phenolic content and antioxidant capacity of quinoa seeds (Chenopodium quinoa Willd.). Industrial Crops and Products. Volume 32, Issue 3, November 2010, Pages 258-263

[23] M. Ghaedi, A. Shokrollahi, A.H. Kianfar, A.S. Mirsadeghi, A. Pourfarokhi, M. Soylak. The determination of some heavy metals in food samples by flame atomic absorption spectrometry after their separation-preconcentration on bis salicyl aldehyde 1,3 propan diimine (BSPDI) loaded on activated carbon J. Hazard. Mater. 154 (2008), pp. 128-134

[24] M. Ibrahim, N. Ahmad, S.A. Anwar. Sewage effluents and soil productivity. International Seminar on Degraded Soils: Process, Management and Analysis, Faisalabad, Pakistan, October 19-24, University of Agriculture (1998) 
[25] Mohammad Wahsha, Claudio Bini, Silvia Fontana, Abeer Wahsha, Diana Zilioli. Toxicity assessment of contaminated soils from a mining area in Northeast Italy by using lipid peroxidation assay.Journal of Geochemical Exploration. Volume 113, February 2012, Pages 112-117

[26] M. Qadir, A. Ghafoor, S.I. Hussain, G. Murtaza, T. Mahmood. Metal ion contamination in vegetables and soils irrigated with city effluent. Proceedings Environmental Pollution: 3rd National Symposium on Modern Trends in Contemporary Chemistry, Islamabad, 24-26 February (1997), pp. 89-92

[27] Muhammad K. Jamali, Tasneem G. Kazi, Muhammad B. Arain, Hassan I. Afridi, Nusrat Jalbani, Ghulam A. Kandhro, Abdul Q. Shah, Jameel A. Baig. Heavy metal accumulation in different varieties of wheat (Triticum aestivum L.) grown in soil amended with domestic sewage sludge. Journal of Hazardous Materials, Volume 164, Issues 2-3, 30 May 2009, Pages 1386-1391

[28] Munir J. Mohammad Rusan, Sami Hinnawi, Laith Rousan. Long term effect of wastewater irrigation of forage crops on soil and plant quality parameters. Desalination. Volume 215, Issues 1-3, 5 September 2007, Pages 143-152

[29] M. Younas, S. Afzal, I.H. Jaffery, M. Farooq. Forms of Cd, Pb, $\mathrm{Zn}$ and $\mathrm{Cr}$ in contaminated soils from raiwind, Lahore, Pakistan. J. Chem. Soc. Pak., 21 (1999), p. 393

[30] N. Sridhara Chary , C.T. Kamalaa, D. Samuel Suman Rajb, Assessing risk of heavy metals from consuming food grown on sewage irrigated soils and food chain transfer. Ecotoxicology and Environmental Safety. Volume 69, Issue 3, March 2008, Pages 513-524

[31] P. C. BROOKES and S. P. McGRATH. Effect of metal toxicity on the size of the soil microbial biomass. Article first published online: 28 JUL 2006

[32] P.G. Ozanne. Chlorine deficiency in soil. Nature, 182 (1958), pp. 1172-1173

[33] Raül S. Lavadoa. Effects of Sewage-Sludge Application on Soils and Sunflower Yield: Quality and Toxic Element Accumulation, journal of plant nutrition. Pages 975-984 2006

[34] R.X. Zhao, W. Guo, Y.Y. Bao, H.J. Yang, J.F. Wang. Characteristics of heavy metals in soils from Bainaimiao copper mining area of grassland ecosystem in Inner Mongolia. Chin J Soil Sci, 43 (2012), pp. 496-500.

[35] S.C. Wilson, R. Duarte-Davidson, K.C. Jones. Screening the environmental fate of organic contaminants in sewage sludge applied to agricultural soils: The potential for downward movement to groundwater. Science of the Total Environment. Volume 185, Issues 1-3, 21 June 1996, Pages 45-57

[36] Sheldon, A., Menzies, N.W., So, H.B., Dalal, R., 2004. The effect of salinity on plant available water. In: Supersoil 2004: Proceedings of the 3rd Australian New Zealand Soils Conference, University of Sydney, Australia, 5-9 December 2004.

[37] S. Khan, A.M. Khan, M.N. Khan. Investigation of pollutant load in wastewater of Hayatabad, Peshawar, Pakistan. Pak. J. Appl. Sci., 2 (4) (2002), pp. 457-461

[38] S.R.O. 549 (I)/2000. Extraordinary published by authority. Isamabad Thursday agust 10,2002.

[39] Steve P. McGrath, Amar M. Chaudri, Ken E. Giller. Longterm effects of metals in sewage sludge on soils, microorganisms and plants. Journal of Industrial Microbiology. February 1995, Volume 14, Issue 2, pp 94-104

[40] S.T. Abbas, M. Sarfraz, S.M. Mehdi, G. Hassan, Obaid-UrRehman.Trace elements accumulation in soil and rice plants irrigated with the contaminated water. Soil and Tillage Research. Volume 94, Issue 2, June 2007, Pages 503-509

[41] Ulrika Olofsson, Anders Bignert, Peter Haglund. Time-trends of metals and organic contaminants in sewage sludge. Water Research. Volume 46, Issue 15, 1 October 2012, Pages 48414851

[42] Wagner Bettiol and Raquel Ghini. Impacts of Sewage Sludge in Tropical Soil: A Case Study in Brazil. Applied and Environmental Soil Science. Volume 2011 (2011), Article ID 212807, 11 pages

[43] X.H. Liu, D.M. Zhou, X.Z. Hao, Y.B. Si, L. Cang, Y.J. Heavy metal pollution of the environment in Jiuhua copper orefield Soils, 39 (2007), pp. 551.

[44] Y.P. Dang, R.C. Dalal, D.G. Mayer, M. McDonald, R. Routley, G.D. Schwenke, S.R. Buck, I.G. Daniells, D.K. Singh, W. Manning, N. Ferguson. High subsoil chloride reduces soil water extraction and crop yield from Vertosols. Australian Journal of Agricultural Research, 59 (2008), pp. 321-330

[45] Zhiyuan Li, Zongwei Ma, Tsering Jan van der Kuijp, Zengwei Yuan, Lei Huang. A review of soil heavy metal pollution from mines in China: Pollution and health risk assessment. Science of The Total Environment. Volumes 468-469, 15 January 2014, Pages 843-853. 